\title{
Светоизлучающие структуры для кремниевой оптоэлектроники на основе локально растянутых Ge микроструктур
}

\author{
А.В. Новиков ${ }^{1)}$, Д.В. Юрасов ${ }^{1)}$, А.Н. Яблонский ${ }^{1)}$, Н.А. Байдакова ${ }^{1)}$, Е.Е. Морозова ${ }^{1)}$, В.А. Вербус ${ }^{1,2)}$, \\ Н.С. Гусев ${ }^{1)}$, Д.В. Шенгуров ${ }^{1)}$, А.В. Нежданов ${ }^{3)}$, А.И. Машин ${ }^{3)}$ \\ ${ }^{1}$ ИФМ РАН, Нижегородская обл., д. Афонино, 603087, ул. Академическая д. 7 \\ ${ }^{2}$ НИУ Высшая Школа Экономики, Нижний Новгород, 603155, ул. Б. Печерская, 25/12 \\ ${ }^{3}$ ННГУ им. Н.И. Лобачевского, Нижний Новгород, 603950, пр. Гагарина д.23 \\ тел:+7 (831) 417-9480, ракс:+7 (831) 417-9464, эл. почта: anov@ipmras.ru
}

DOI 10.34077/RCSP2019-70

$\mathrm{B}$ последние годы Ge становится одним из ключевых материалов кремниевой фотоники. В частности значительные надежды связываются с применением деформированного (растянутого) $\mathrm{Ge}$ для решения проблемы создания на кремнии эффективного источника излучения ближнего ИК диапазона. Физическим обоснованием этих надежд является уменьшение исходно небольшого (134 мэВ при $300 \mathrm{~K})$ энергетического зазора между прямой и непрямой запрещенными зонами Ge при его растяжении. Однако уровни деформации, необходимые для существенного уменьшения этого зазора, значительны: зазор становится нулевым при двухосной деформации в 1.5-2 \% или одноосной вдоль направления (100) в 4.5-5\%. Столь высокие значения деформации труднодостижимы в сплошных Ge пленках. Поэтому в настоящее время активно ведутся работы по созданию локально деформированных Ge микроструктур и исследованию их излучательных свойств. В настоящей работе представлены результаты по формированию одноосно деформированных Ge микроструктур и исследованию их спектров люминесценции.

Для создания деформированных $\mathrm{Ge}$ микроструктур использовались релаксированные $\mathrm{Ge}$ слои, выращенные методом МПЭ на $\mathrm{Si}(001)$ или SOI подложках, которые из-за разницы коэффициентов термического расширения $\mathrm{Si}$ и Ge характеризовались двуосной деформацией растяжения $0.2 \div 0.25 \%$. Данная деформация может быть многократно увеличена при формировании метод “концентрации напряжений" [1] микроструктур типа «микромостика». Локальные измерения распределения деформации, выполненные методом микро-КРС, показали возрастание деформации в центре микромостиков более чем на порядок по сравнению с исходной $\mathrm{Ge}$ пленкой [2]. Для решения проблемы теплоотвода от свободновисящих микромостиков использовались подложки SOI с тонкими слоями захороненного окисла и кремния над ним (200 и 100 нм, соответственно). Это позволило за счет адгезии реализовать механический контакт между подложкой и микромостиком после его формирования («подвешивания»). Проведенные исследования показали, что реализация такого подхода позволяет в несколько раз увеличить плотность оптической накачки, которая приводит к разрушению микромостиков. Методом микро-ФЛ при комнатной температуре выполнены подробные

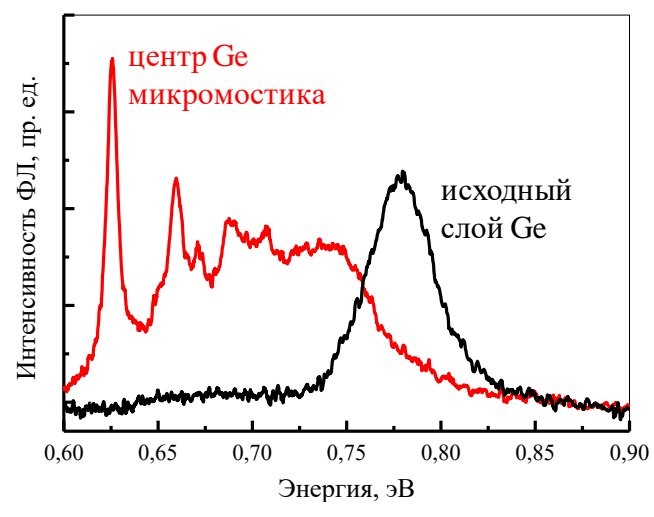

Рис. 1. Спектры микро-ФЛ исходного слоя $\mathrm{Ge}$ и микромостика. исследования модификации спектров ФЛ при возбуждении различных частей сформированных $\mathrm{Ge}$ микроструктур. Показано значительное возрастание интегральной интенсивности сигнала ФЛ в области микромостиков и его сдвиг в область меньших энергий по сравнению с исходной Ge пленкой, (рис. 1). Данные изменения вызваны уменьшением ширин прямой и непрямой запрещенных зон и энергетического зазора между ними при одноосном растяжении $\mathrm{Ge}$ вдоль направления типа (100). Выявлено, что форма сигнала ФЛ от микромостиков в значительной мере определяется интерференционными эффектами, вызванными отражением излучения от внешних границ микроструктуры (рис. 1). Установлена преимущественная поляризация излучения от микромостиков. Обсуждается возможность использования различных микрорезонаторов для увеличения эффективности вывода излучения из локально деформированных Ge микроструктур и достижения в них стимулированного излучения.

Работа выполнена при поддержке гранта РФФИ № 16-29-14056-офи_м.

Лumepamypa

[1] R. Geiger, T. Zabel, H. Sigg // Front. Mater. 2015. V.2, P.52.

[2] А.В. Новиков и др. // ФТП. 2018. Т.52, вып. 11. С. 1131-1136. 